\title{
The Larval Stages of Notomastus latericeus Sars.
}

\author{
By \\ Douglas P. Wilson, M.Sc., \\ Assistant Naturalist at the Plymouth Laboratory. \\ With one Plate.
}

CONTENTS.

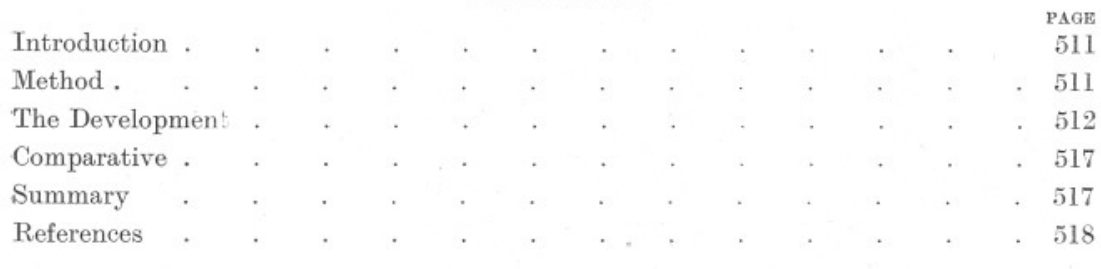

\section{INTRODUCTION.}

OF no species of Notomastus has the development yet been described, so that a brief account of the general appearance of the larvæ of a member of this genus is not without interest and should be of value to plankton workers. For the closely allied genus Capitella we are indebted to Eisig (2) for an exhaustive treatise on the embryology of $C$. capitata. It seems likely that in its main histological details the development of Notomastus will follow closely that of Capitella ; indeed the few external differences that are here shown to exist are of quite minor importance.

\section{Method.}

Notomastus latericeus is a common inhabitant of the soft mud banks of the Salcombe estuary, especially in the upper region near the Salstone. There the adults were collected, sometimes by myself and sometimes for me by Mr. William Searle. The worms were usually found coiled in a spiral burrow and were placed with as little disturbance as possible in jars of mud for conveyance to Plymouth. During the journey they invariably broke themselves up into many pieces, which however remained alive for a few hours. They were dealt with at once on arrival at the Laboratory, mature-looking pieces being washed free from mud and slit with needles in small dishes of filtered outside sea-water. Eggs were transferred to finger-bowls, fertilised, and washed free from sperm. 
Larvæ which swam up to the surface on the following day were pipetted off into finger-bowls or plunger-jars. All outside sea-water used was passed through a Berkefeld filter and Nitzschia (kindly supplied by Dr. Allen) was added for food. Drawings to scale were made of the living larvæ with the aid of a squared net micrometer and squared paper. On account of their extreme activity it was necessary to trap the larvæ lightly beneath a supported cover-glass. Specimens fixed in Bouin at $60^{\circ} \mathrm{C}$. were mounted and used to check the drawings.

The above method of making the fertilisation is in this species probably more artificial than usual, as copulation is the general rule for Capitellids, and is said to occur in Notomastus. Capitella in addition broods its eggs until the larvæ swim away. According to Eisig (1, p. 286) no other genus of the family does this.

Successful fertilisations were made in April and June, 1928, and in May, 1932. In each case the larvæ were reared through the metamorphosis and for about twelve days afterwards. The times given in this paper are for the May rearing in 1932, when the Laboratory air temperatures for the first eleven days of the development (from fertilisation to metamorphosis) averaged $58.6^{\circ} \mathrm{F}$. and for the succeeding eleven days $61.5^{\circ} \mathrm{F}$. The temperature of the water in the plunger-jar would be approximately the same.

\section{The Development.}

The newly shed unfertilised egg is approximately $150 \mu$ in diameter and is closely invested in a relatively thick $(3-4 \mu)$ membrane. There is a large and fairly conspicuous germinal vesicle, and large numbers of oilylooking yolk globules. The general colour is greyish by both transmitted and reflected light.

About fifteen hours after fertilisation the larvæ begin to swim by means of the prototroch and before the appearance of the telotroch and apical tuft. The cilia can be seen to pass through the egg membrane, which separated from the egg surface (possibly as a fertilisation membrane) before the first cleavage. This membrane from now on forms a cuticle round the larva. According to Eisig (2, pp. 44 and 98) it does not do this in Capitella but is thrown off about the third day, being replaced by a cuticle formed underneath. His evidence, however, does not seem very satisfactory and as I have not seen it thrown off in Notomastus and as appearances are all to the contrary, I believe it to persist as stated.

Twenty-four hours later the trochosphere stage, shown in Plate 1, Fig. 1, is reached. The larva is widest in the region of the prototroch, which forms a broad band of rapidly beating cilia. It is not quite a complete ring as there is a very slight dorsal gap, which however soon closes 
up. The telotroch is also a band of cilia, shorter than those of the prototroch, and it likewise has a gap, only ventrally. An apical tuft of about fifteen long and fairly strong cilia springs from the anterior end, directed forwards in the line of movement. The motion forwards is relatively very rapid. The endoderm forms a large central mass of big cells, the outlines of which are clearly visible. These cells are crowded with large oily yolk globules. The blastocœl is almost completely occluded. The ectoderm is thick, practically colourless and with few oil globules. Its cell boundaries are faintly visible. The stomodæal invagination is visible as a transverse slit just posterior to the prototroch in the mid-ventral line.

A few hours later additional cilia are acquired: a broad neurotroch which passes through the ventral gap in the telotroch in its course from mouth to anus; a narrow metatroch of short posteriorly directed cilia immediately behind the prototroch, a complete ring except where it is interrupted by the mouth; and three patches of short beating cilia close to the apical tuft. Of these three patches one is median and forms a semicircle tending to embrace the base of the long apical tuft dorsally; the other two are short arcs situated a little more posteriorly, one on either side. A pair of eyespots composed of a few reddish brown globules appears. Each eyespot is situated laterally just anterior to the prototroch. The larva becomes contractile, and the apical plate can be indented. It elongates and widens posteriorly, narrowing in the region of the prototroch. In this way is reached the four days' old stage shown in Plate 1, Fig. 2. The trunk is now segmented, the first segment-peristomiumbeing bristleless, the following three just beginning to grow a bristle from each noto- and neuropodium, the notopodial being the more advanced. The anterior extremities of these segments are indicated approximately by irregular bands of colourless but refringent ectodermal globules. A similar band is present anterior to the prototroch, while similar globules are scattered on the prostomium and the pygidium. The central greenish yellow yolk mass of numerous large globules is conspicuous. Its cell boundaries are less distinct than before. The cuticular membrane (egg or fertilisation membrane) is thinner than previously as though it had been stretched by increase in size of the contained larva. By the time the stage shown in Plate 1, Fig. 3 , is reached it is only about $1 \mu$ thick. No attempt has been made to show it in Fig. 2 and subsequent drawings.

From now on the most striking feature of the larvæ is their extreme contractility. The drawings-which are little better than caricatures of extremely beautiful creatures-show as closely as could be judged the normally extended or resting condition. At extreme extension larvæ are considerably longer than this, at contraction much shorter. The stage of Fig. 3 can contract into a ball. When lightly trapped beneath a coverglass contractile activity is exhibited with great vigour. 
PLATE 1.
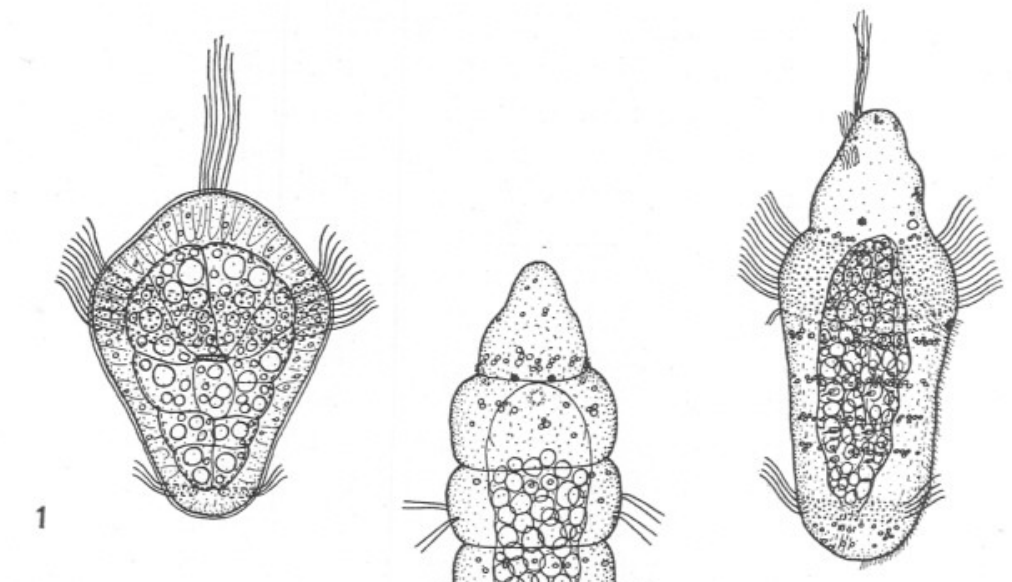

3
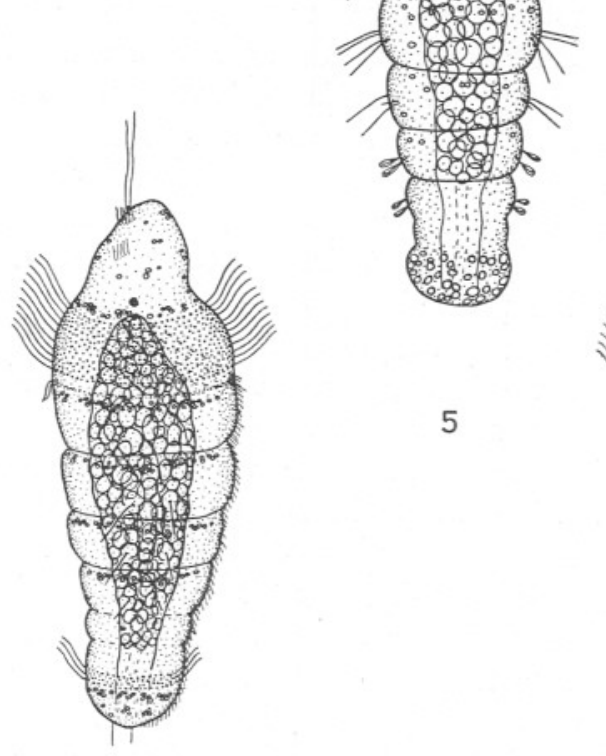

5
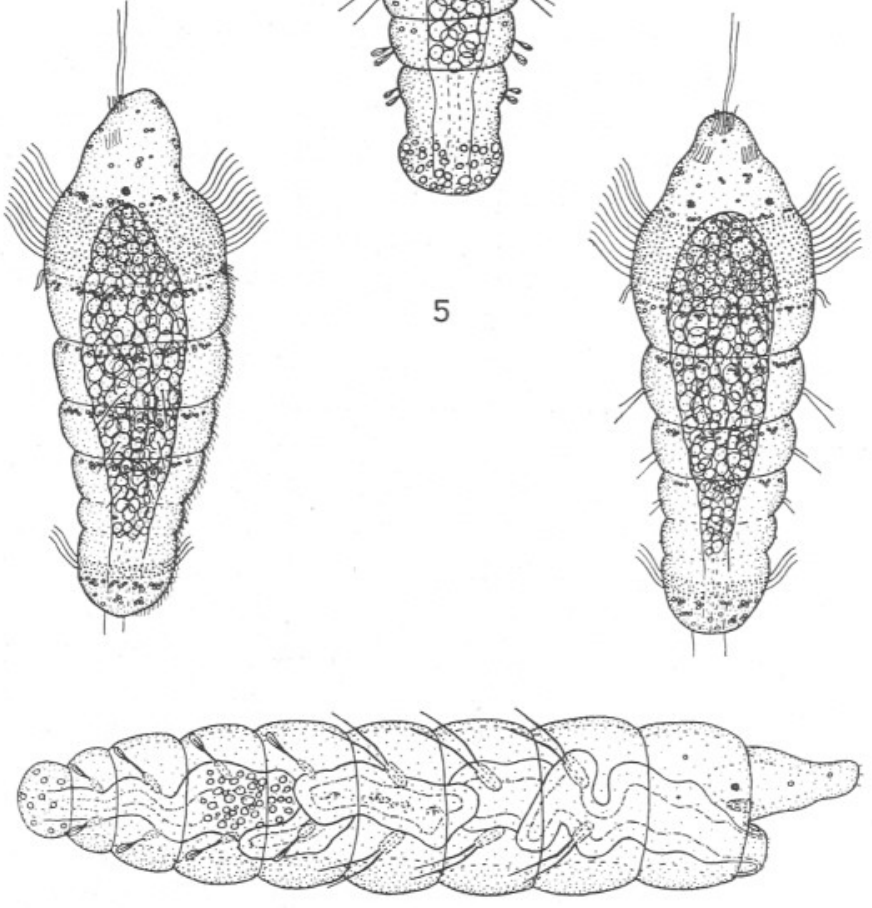

6

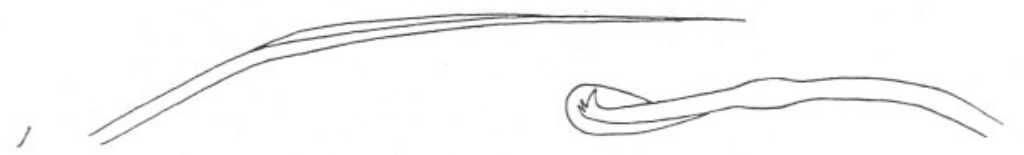


The larva continues to elongate and the segmentation becomes more distinct (Plate 1, Figs. 3 and 4). The bristles, one dorsal and one ventral in each parapodium, are much longer. The fourth chætigerous segment is marked out and is obtaining noto- and neuropodial hooks, the former being more advanced than the latter. At this stage, six days from fertilisation, the long apical cilia are fewer in number and are probably falling off. Figs. 3 and 4 show two cilia still remaining although many larvæ otherwise similar have quite lost them. There is individual variation as to the time at which they are lost. There are two or three very fine sensory cilia near the anus ; these only last a few days. The majority of the larvæ swim actively just clear of the bottom, unless stirred up away from it, and a day or so later may even rest thereon. This is in contrast to the earliest stages which crowded up to the surface. They now crawl well under a cover-glass.

Four or five days later when the larvæ are about ten days old the external cilia are lost, including the neurotroch which is the last to disappear. The disappearance of the prototroch is gradual and apparently takes place in stages, as larvæ with very narrow prototrochs are seen. Such larvæ still retain the metatroch. Whether any part of the prototroch is thrown off as Eisig (2, p. 81) described for Capitella, or whether it is all absorbed internally, is uncertain as no such throwing oft has been seen and the matter has not been investigated in histological detail. The loss of the broad prototroch results in the prostomium directly joining on to the peristomium as a comparison of Figs. 4 and 5 will make clear.

At the time the prototroch is lost the larva has about five chætigerous segments, the first three with two bristles in each noto- and neuropodial bundle, the last two with a single dorsal and ventral-hooded hook on either

\section{EXPLANATION OF PLATE I.}

Larvæ and juveniles of Notomastus latericeus Sars. Drawings 1-6 from life, $\times 156$. Drawings 7 and 8 by camera lucida, $\times 1380$. All measurements given below exclude apical cilia. Ages are for May rearing, 1932.

In these drawings the cilia and their distribution are of necessity illustrated very diagrammatically, and the same remark applies to the central yolk mass.

FIG. 1.-Ventral view about 40 hours after fertilisation. Actual length approx. $210 \mu$ (see page 512).

FIG. 2.-View of right side, four days old. Actual length approx. $285 \mu$ (see page 513).

Fig. 3.-View of right side, six days old. Actual length approx. $335 \mu$ (see page 515).

FIG. 4.-Dorsal view of same stage as Fig. 3 .

FIG. 5.-Dorsal view of a young worm eleven days old and recently metamorphosed. Actual length approx. $380 \mu$ (see page 516).

Fig. 6.-Lateral view of a young worm twenty-three days old. Actual length approx. $535 \mu$ (see page 516).

Fic. 7.-Outline of a bristle from a young worm.

Fig. 8.-Outline of a hook from a young worm.

NEW SERIES.-VOL. XVIII. NO. 2. JANUARY, 1933. 
side. There is, however, considerable variation as to the age and stage at which the swimming girdles are lost and a twelve-day old larva with six chætigerous segments possessed a set of cilia complete even to the apical tuft. On the other hand, in the April rearing of 1928, several larvæ seven days old and with only four chætigerous segments had lost all their cilia except the neurotroch which disappeared a little later.

A recently metamorphosed worm eleven days old is shown in Fig. 5. On either side at the junction of the prostomium with the peristomium can be seen one of the pair of nuchal organs. These had been seen while the prototroch was still present, they were just anterior to it. The eyes are deep seated and as the worm expands and contracts they move backwards and forwards relative to the anterior boundary of the peristomium. The refringent ectodermal globules form less definite bands on the segments than formerly. The pygidium is crowded with them. Yolk appears to be present in less quantity than before and is situated mainly dorsally. Cell outlines of the gut cannot be made out. The introvert is forming anteriorly, but the worm does not yet seem to be feeding. Worms at this stage crawl actively on the bottom of the plunger-jar.

Fig. 6 shows in lateral view a young worm from the bottom of a plungerjar twelve days later, twenty-three days after fertilisation. Seven chætigerous segments are present, the first three with two winged bristles in each bundle, the last four with a single-hooded hook in each noto- and neuropodium. Outlines of a bristle and a hook are shown in Figs. 7 and 8 . The pygidium has become smaller. Most of the yolk is used up, a little remaining in the gut walls rather posteriorly. Anterior to this the gut is longer than the worm at normal extension and is thrown into loops. The introvert is protrusible and has been for a few days; in the drawing it is shown partially protruded. Since it could be everted the worm has been feeding, for the gut has contained brown diatomaceous material for some days past. The creature is beautifully transparent and colourless, the septa and the muscles moving the chæta-sacs can be seen, and large corpuscles floating in the cœlomic fluid are very noticeable. The definite bands of refringent ectodermal globules have disappeared. A few short sensory cilia have appeared on the tip of the prostomium. These young worms crawl very actively under a cover-glass, and also at times on the bottom of finger-bowls, but in the latter they often remain in one place for a considerable period.

I have not been able to rear the young worms much further than the stage just described. Probably they require mud rich in a variety of small living creatures suitable for food. It is difficult however to keep such mud in a satisfactory condition in a plunger-jar or a finger-bowl, and attempts to rear these larvæ in mud have so far failed. No doubt they could be reared easily if the right conditions were found and maintained. 


\section{Comparative.}

It is in the apparent lack of highly specialised larval organs adapting it to a pelagic existence that the Notomastus larva is of interest in comparison with some other Polychætes. The absence of long provisional bristles, or a spacious blastocœl or a prototroch enlarged in diameter, such as some others possess (e.g. Sabellaria, Polydora, Owenia, Polygordius, etc.), may perhaps be correlated with what seems to be a relatively high swimming speed and an unprolonged pelagic life. But the comparison must not be pressed too far, for swimming speeds have not been measured, nor do we yet know enough about the larvæ of all groups of Polychætes to enable such generalisations to be made.

A few points in comparison with Capitella as described by Eisig (2) are of interest. In Notomastus there are about five chætigerous segments marked out at the time when the cilia are lost, but in Capitella there are thirteen. The age at that time is about the same, but as actual temperatures cannot be compared little meaning can be attached to this. If one can judge from some of Eisig's figures the prototroch of Capitella is not as broad a band as that of Notomastus, nor does it appear to be followed by a metatroch. Bearing these considerations in mind one can state definitely that the larva figured by McIntosh (3, Plate XCIII, Fig. 10), and thought by him (p. 275) to be possibly that of Notomastus latericeus, is not so. It has too many parapodia, too narrow a prototroch and is the wrong colour.

\section{SUMMARY.}

1. Artificial fertilisations of Notomastus latericeus Sars were made and the larvæ reared.

2. The two-day old trochosphere is provided with a large central mass of yolk. It has a broad prototroch, a telotroch, a neurotroch and an apical tuft. It swims rapidly.

3. Development consists in the appearance of trunk segments. The most anterior of these is the achætous peristomium. Those following acquire neuro- and notopodial chætæ.

4. At an age of about ten days the cilia are gradually lost. The larva then has about five chætigerous segments, the first three bearing bristles, the last two hooded hooks.

5. The young worms lived for some twelve days after metamorphosis and by that time had seven chrtigerous segments. Only a little of the yolk still remained. The worms possessed a protrusible introvert and were feeding on diatoms. 
6. The larva apart from its strong prototroch and rapidity of swimming does not exhibit any special structural adaptations to pelagic life, such as are found in some other Polychæte larvæ. In comparison with Capitella it has fewer segments when it metamorphoses.

\section{REFERENCES.}

1. Eisig, H. 1887. Die Capitelliden des Golfes von Neapel. Fauna und Flora des Golfes von Neapel. Monographie, XVI.

2. 1899. Zur Entwicklungsgeschichte der Capitelliden. Mitt. Zool. Sta. Neap. Bd. 13, pp. 1-292.

3. McIntosh, W. C. 1915. A Monograph of the British Marine Annelids. Vol. III. The Ray Society. London. 